\title{
Growth and Yield of Fenugreek (Trigonella foenum-graecum L.) Varieties as Influenced by Application of NPS Fertilizer at Ginir, South-eastern Ethiopia
}

\author{
Chala Gutema ${ }^{1, *}$, Jemal Abdullahi ${ }^{2}$, Tamado Tana ${ }^{2}$ \\ ${ }^{1}$ Oromia Agricultural Research Institute, Sinana Agricultural Research Centre, Bale-Robe, Ethiopia \\ ${ }^{2}$ Department of Plant Sciences, Haramaya University, Dire Dawa, Ethiopia
}

Email address:

chalagutema@gmail.com (C. Gutema)

${ }^{*}$ Corresponding author

To cite this article:

Chala Gutema, Jemal Abdullahi, Tamado Tana. Growth and Yield of Fenugreek (Trigonella foenum-graecum L.) Varieties as Influenced by Application of NPS Fertilizer at Ginir, South-eastern Ethiopia. Agriculture, Forestry and Fisheries. Vol. 10, No. 2, 2021 , pp. 66-74. doi: $10.11648 /$ j.aff.20211002.15

Received: December 15, 2020; Accepted: December 31, 2020; Published: March 10, 2021

\begin{abstract}
Shortage of improved varieties and soil nutrient depletion are the major production constraints of fenugreek in mid-altitude of Bale Zone in Ethiopia. Therefore, an on-farm experiment was conducted at Ginir, south-eastern Ethiopia, to assess the effect of NPS fertilizer rates on growth and, yield components and seed yield of fenugreek varieties. Factorial combinations of three fenugreek varieties (Burqa, Chala and Ebisa) and five rates of NPS (0, 50, 100, 150 and $\left.200 \mathrm{~kg} \mathrm{NPS} \mathrm{ha}^{-1}\right)$ were laid out in a randomized complete block design (RCBD) with three replications. Analysis of variance showed that the main effects of varieties significantly influenced days to $50 \%$ flowering, days to $90 \%$ physiological maturity and thousand seed weight. The highest thousand seed weight $(17.31 \mathrm{~g})$ was recorded from variety Burqa. Variety Chala was the earliest to reach days to $50 \%$ flowering ( 63.27 days) while variety Burqa was the earliest (115 days) to reach $90 \%$ of physiological maturity. Similarly, the main effect of NPS showed significantly higher number of primary branches per plant (5.11), number of pod per plant (25.47) and biomass yield (7160 kg ha $)$ at $200 \mathrm{~kg} \mathrm{NPS} \mathrm{ha}^{-1}$ while the highest thousand seed weight (18.44g) was obtained at $150 \mathrm{~kg} \mathrm{NPS} \mathrm{ha}{ }^{-1}$. The interaction of NPS fertilizer and varieties showed significant effect on plant height, number of seeds per pod and seed yield. The highest plant height $(53.67 \mathrm{~cm})$ was recorded from Chala variety at $200 \mathrm{~kg}$ NPS fertilizer $\mathrm{ha}^{-1}$ while the highest number of seeds per pod (11.89) was recorded from variety Burqa at $150 \mathrm{~kg}$ NPS fertilizer ha ${ }^{-1}$. Similarly, the highest seed yield $\left(1980 \mathrm{~kg} \mathrm{ha}^{-1}\right)$ was recorded from variety Ebisa at $150 \mathrm{~kg}$ NPS fertilizer ha ${ }^{-1}$. The economic analysis revealed that the highest net return of (42231.67 and 40361.9 $\mathrm{ETB} \mathrm{ha}^{-1}$ ) with marginal rate of return (566.84 and 542.5\%) were recorded for varieties of Ebisa and Chala respectively, while variety Burqa resulted in the higher net benefit (39294.8 ETB ha ${ }^{-1}$ ) with the highest marginal rate of return (166.24\%) at $100 \mathrm{~kg}$ NPS ha $^{-1}$. Therefore, it can tentatively be concluded that application of $150 \mathrm{~kg} \mathrm{NPS} \mathrm{ha}^{-1}$ Ebisa and Chala varieties and $100 \mathrm{~kg} \mathrm{NPS} \mathrm{ha}^{-1}$ of variety Burqa to be the best treatment in the study area.
\end{abstract}

Keywords: Varieties, Economic Evaluation, Fenugreek, NPS Fertilizer, Seed Yield

\section{Introduction}

Fenugreek (Trigonella foenum-graecum L.) is a multipurpose spice crop; every part of the plant is being used as leafy vegetable, fodder and condiment [1]. In Ethiopia, fenugreek-growing regions are the high plateaus (1800-2300 m.a.s.l.) characterized by subtropical climate of wet and dry seasons [2].
Nitrogen fertilization improved morphological parameters (plant height, number of branches, stem weight), yield components (thousand seed weight), and total protein content of fenugreek [3]. The deficiency of Phosphorus followed by $\mathrm{N}$ is the major constraint in pulse production since Phosphorus affects growth, nodule formation and development and N-fixation [4]. Sulphur (S) which has now emerged as the fourth important plant nutrient to crops. 
Sulphur plays a vital role in plant metabolism. There is no information on the impact of different types of fertilizers except nitrogen and phosphorous on the yield and other traits of fenugreek at Bale Zone. Based on the EthioSIS (Ethiopian soil Information System) soil analysis report of 2014, Ginir area soil lacks $\mathrm{S}, \mathrm{Zn}, \mathrm{Fe}$ and $\mathrm{B}$ in addition to the $\mathrm{N}$ and $\mathrm{P}$ [5].

In Ginir, district of Bale Zone, fenugreek is one of the major seed spice crops produced for the purpose of both home consumption and market. However, its production constraints are poor soil fertility, especially nitrogen, phosphorous and Sulphur deficiency. Besides, lack of improved varieties, shortage of certified seeds, weeds, diseases like powdery mildew and root rot and insect pests such as aphids are also the limiting factors [6]. It is, therefore, necessary to improve fenugreek productivity through different fertilizer management and selection of varieties with high fertilizer use efficiency to make fenugreek production rewarding to farmers, and to satisfy the demand of fenugreek both in local and international market.

Therefore, the objectives of the study were:

1. to assess the effect of NPS fertilizer rates on growth, yield components and seed yield of fenugreek; and

2. to identify economically feasible rate/s of NPS fertilizer for fenugreek production

\section{Materials and Methods}

\subsection{Description of Experimental Area}

The experiment was conducted at Ginir mid altitude of Bale, Oromia Regional State, and South eastern Ethiopia during the main cropping season of 2017 to 2019. Ginir is located $519 \mathrm{~km}$ away from Addis Ababa to South eastern, 86 $\mathrm{km}$ away from the zonal capital town, Robe. It is located at $07^{\circ} 15^{\prime} \mathrm{N}$ latitude and $40^{\circ} 66^{\prime} \mathrm{E}$ longitude at $1972 \mathrm{~m}$ above sea level [7]. The area has bimodal rainfall patterns. Based on this there are two separate crop growing seasons locally called bona and gana. The main season bona extends from September to November and gana from March to May. The soil type is Vertisols. The major crops grown widely in the area are cereals (wheat, barley, maize and tef, pulses (chickpea, field pea, faba bean, and lentil), seed spices (black cumin, coriander and fenugreek) and vegetables (onion, garlic, potato and tomato) under rain fed and irrigation.

\subsection{Experimental Materials}

\subsubsection{Planting Material}

The fenugreek varieties Ebisa and Burqa which were released by Sinana Agricultural Research Centre (SARC) in 2006 and 2016 respectively and Chala which was released by Debrzeit Agricultural Research Center (DZARC) in 2005 were used in the experiment.

\subsubsection{Fertilizer Material}

The NPS $\left(19 \% \mathrm{~N}, 38 \% \mathrm{P}_{2} \mathrm{O}_{5}\right.$ and $\left.7 \% \mathrm{~S}\right)$ was used as the sources of fertilizer because these nutrients are the most production constraints of fenugreek in the study area.

\subsection{Soil Sampling and Analysis}

Before sowing, soil samples $(0-30 \mathrm{~cm}$ depth $)$ were collected diagonally from five spots from the entire experimental field and mixed to have one composite sample. The composite sample was air-dried, ground using a pestle and a mortar and allowed to pass through a 2-mm sieve. Working samples were obtained from submitted bulk samples were analysis for organic carbon, total $\mathrm{N}$, available sulphur and cation exchange capacity (CEC), soil pH, available phosphorus and soil texture.

\subsection{Treatments and Experimental Design}

The treatments consisted of factorial combination of five rates of NPS fertilizer $\left(0,50,100,150\right.$ and $\left.200 \mathrm{~kg} \mathrm{ha}^{-1}\right)$ and the three fenugreek varieties (Ebisa, Burqa and Chala) in factorial combinations. The experiment was laid out in a randomized complete block design in three replications.

\subsection{Experimental Procedure and Field Management}

The experimental field was ploughed and disked by tractor and pulverized to a fine tilth by hand digging. Blocking and the required number of rows were marked in each plot according to the spacing proposed and rows were made to plant the seeds. The plots were leveled manually. The gross plot size of $2.1 \mathrm{~m} \times 3 \mathrm{~m}\left(6.3 \mathrm{~m}^{2}\right)$ which contain seven rows and the varieties were planted by spacing of $30 \mathrm{~cm}$ and $10 \mathrm{~cm}$ between rows and plants respectively. The four middle rows were used for data collection and one row was for destructive sampling. Two rows were left out as border rows to protect border effects.

\subsection{Data Collected and Measurement}

Phonological, yield components and yield data such as days to $50 \%$ of flowering, days to $90 \%$ maturity, plant height, number of primary branches per plants; number of pod per plant, number of seeds per pod, thousand seed weight, aboveground dry biomass yield, Seed yield and harvest index will be collected and subjected to analysis of variance (ANOVA) procedure using GenStat $16^{\text {th }}$ edition software [8]. Comparisons among treatment means with significant difference for measured characters were done by using Fisher's protected Least Significant Difference (LSD) test at $5 \%$ level of significance.

\subsection{Economic Analysis}

The economic analysis was carried out by using the methodology described in CIMMYT in which prevailing market prices for inputs at planting and for outputs at harvesting. The concepts used in the partial budget analysis were started from adjusted the yield downward by $10 \%$ for management difference and the mean seed yields for NPS treatment combinations were subjected to a discrete economic analysis using the procedure recommended by CIMMYT [9]. 


\section{Results and Discussion}

\subsection{Soil Physico-chemical Properties of the Experimental Site}

The physico-chemical properties of the soil were determined for composite soil $(0-30 \mathrm{~cm}$ depth) samples collected before sowing (Table 1). Accordingly, the texture of the soil of the experimental site is dominated by the clay fraction. Thus, on the basis of particle size distribution, the soil contains $21 \%$ sand, $27 \%$ silt, and $52 \%$ clay.

The soil has a medium content of available phosphorus (10.23 ppm), according to the rating of Cottenie which indicates the requirement for application of another phosphorus fertilizer sources for crop growth and yield [10]. The results showed that, the soil had low organic carbon content $(1.18 \%)$ indicating its low potential to supply nutrients especially $\mathrm{S}$ to plants through mineralization, since the major source of $\mathrm{S}$ (about 95\%) is organic matter [11]. According to the rating of Lewis the level of available sulphur $(21.42 \mathrm{ppm})$ is very low, suggesting a requirement for $\mathrm{N}$ and $\mathrm{S}$ fertilizer application [12]. The $\mathrm{pH}$ of the experimental site is neutral (6.82) according to the rating of Murphy and Tekalign Tadesse [13] and [14]. According to FAO the suitable $\mathrm{pH}$ range for most crops is between 6.5 and 7.5 in which $\mathrm{N}$ availability is optimum [15].

According to Landon top soils having CEC greater than 40 $\mathrm{cmol}(+) / \mathrm{kg}$ are rated as very high, $25-40 \mathrm{cmol}(+) / \mathrm{kg}$ as high, $15-25 \mathrm{cmol}(+) / \mathrm{kg}$ as medium, $5-15 \mathrm{cmol}(+) / \mathrm{kg}$ low and $<5 \mathrm{cmol}(+) / \mathrm{kg}$ of soil as very low [11]. According to this classification, the present study soil has very high CEC of $47.46 \mathrm{cmol}(+) / \mathrm{kg}$ soil indicating its very high capacity to retain the cation. Tekalign Tadesse classified soil total $\mathrm{N}$ availability of $<0.05 \%$ as very low, $0.05-0.12 \%$ as low, 0.12 $0.25 \%$ as medium and $>0.25 \%$ as high [14]. The present study soil total $\mathrm{N}$ was estimated to be $0.16 \%$ (medium) indicating that the nutrient is a limiting factor for optimum crop growth. Therefore, based on the current laboratory results, the soil of the experimental site is suitable for fenugreek growth and production.

Table 1. Selected soil physico-chemical properties of the experimental site before planting

\begin{tabular}{llll}
\hline Properties & Result & Rating & References \\
\hline 1. Physical properties & & & - \\
Sand (\%) & 21 & & - \\
Silt $(\%)$ & 27 & & - \\
Clay $(\%)$ & 52 & & - \\
Textural Class & Clay & & - \\
2. Chemical properties & & Neutral & Tekalign $(1991)$ \\
pH $\left(1: 2.5 \mathrm{H}_{2} \mathrm{O}\right)$ & 6.82 & Low & Tekalign $(1991)$ \\
Organic Carbon $/ \mathrm{OC} /(\%)$ & 1.18 & very high & Roy et al (2006) \\
CEC $\left(\mathrm{cmol} \mathrm{kg}{ }^{-1}\right)$ & 47.46 & Medium & Tekalign $(1991))$ \\
Total nitrogen $/ \mathrm{TN} /(\%)$ & 0.16 & Medium & Roy et al (2006) \\
Available phosphorus $/ \mathrm{P} /(\mathrm{ppm})$ & 10.23 & Very low & Lewis $(1999)$ \\
Available sulfur $/ \mathrm{S} /(\mathrm{ppm})$ & 21.42 & & \\
\hline
\end{tabular}

\subsection{Crop Phenology and Growth Parameters}

\subsubsection{Days to 50\% Flowering}

Number of days to $50 \%$ flowering was highly significantly $(p<0.01)$ and significantly $(p<0.05)$ affected by the main effects of NPS rates and varieties of fenugreek, respectively while the interaction effect of NPS and varieties did not show significant effect on days to $50 \%$ flowering. As the rate of NPS increasing from zero to $200 \mathrm{~kg} \mathrm{ha}^{-1}$ the number of days required to reach $50 \%$ flowering was significantly from 65.89 days to 62.11 days (Table 2). This might be due to the fact that phosphorus enhances reproductive phase through fastened flowering. In agreement with this result, Gifole et al. reported that phosphorus application to haricot bean significantly reduced days to flowering [16].

In Fenugreek the days to $50 \%$ flowering were significantly influenced by varieties. Variety Chala had the shortest days (63.27 days) to reach days to $50 \%$ flowering while Burqa and Ebisa varieties took the longest days of 64.20 and 64.53 to flowering. This is due to their genetic difference in response to flowering. Nchimbi-Msolla and Tryphone reported significant differences in the number of days required to reach 50\% flowering among 20 common bean genotypes. The result is also in line with the finding of Abera, who reported that where chickpea applied with $20 \mathrm{~kg} \mathrm{P}_{2} \mathrm{O}_{5} \mathrm{ha}^{-1}$ delayed days to flowering (52.67 days) [18].

\subsubsection{Days to 90\% Physiological Maturity}

The analysis of variance showed that main effect of NPS and varieties highly significantly $(\mathrm{p}<0.01)$ influenced the number of days required to reach physiological maturity. However, significant variation was not observed due to the interaction between varieties and NPS fertilizer. As the rate of NPS increasing; significantly the duration required to reach physiological maturity was decreased. Thus, plants with no application of the NPS fertilizer required the longest number of days (117.6 days) to reach physiological maturity, whereas those treated with the highest rate of NPS $(200 \mathrm{~kg}$ $\mathrm{ha}^{-1}$ ) required the lowest days (114.2 days) to reach physiological maturity (Table 2). The decreased number of days required to reach physiological maturity in response to increased rates of NPS fertilizer may be resulted to the enhanced availability of the nutrient in the soil and its increased uptake by the fenugreek plants, which might have 
resulted in a more luxurious vegetative growth that resulted in delayed maturity.

This result is in line with that of Abera, who reported that days to $90 \%$ physiological maturity of chickpea was highly significantly $(\mathrm{p}<0.01)$ affected by application of $\mathrm{P}$ fertilizer rate, where, the longest time to maturity (114 days) was recorded for the application of $20 \mathrm{~kg} \mathrm{P}_{2} \mathrm{O}_{5} \mathrm{ha}^{-1}$ [18]. Furthermore, Ibsa reported that days to maturity of chickpea was significantly $(\mathrm{p}<0.01)$ extended by the applied soil fertility treatments (Rhizobium $+46 \mathrm{~kg} \mathrm{P}_{2} \mathrm{O}_{5} \mathrm{ha}^{-1}$ ). $\mathrm{He}$ reported the shortest maturity time observed for the control, where, inoculation in combination with $\mathrm{P}$ application, resulted in the longest (104 days) growing period of chickpea than the control (101 days) [19].

The results showed that variety Ebisa required significantly higher number of days (117 days) while variety Burqa required shortest days (115) to reach physiological maturity (Table 1). The difference might suggest distinction in genetic makeup of the cultivars of fenugreek. In agreement with this result, [20] reported a wide variability of fenugreek landraces for days to maturity with the maximum days required to reach physiological maturity on 166.3 days and the minimum days needed was 116 days. Similarly, million reported that with respect to maturity of fenugreek landraces in Ethiopia, six landraces and the commercial variety Chala (126 days) were the earlier to mature [21].

Table 2. Main effects of NPS fertilizer and varieties on days to $50 \%$ flowering, days to $90 \%$ maturity and number of primary branches of fenugreek.

\begin{tabular}{llll}
\hline Treatment & Days to 50\% flowering & Days to $\mathbf{9 0 \%}$ maturity & Number of primary branches per plant \\
\hline Rate of NPS $\left(\mathrm{kg} \mathrm{ha}^{-1}\right)$ & & & \\
0 & $65.89^{\mathrm{a}}$ & $117.60^{\mathrm{a}}$ & $4.47^{\mathrm{b}}$ \\
50 & $64.78^{\mathrm{ab}}$ & $117.40^{\mathrm{a}}$ & $4.51^{\mathrm{b}}$ \\
100 & $63.89^{\mathrm{bc}}$ & $116.10^{\mathrm{b}}$ & $4.56^{\mathrm{b}}$ \\
150 & $63.33^{\mathrm{c}}$ & $115.40^{\mathrm{bc}}$ & $4.69^{\mathrm{b}}$ \\
200 & $62.11^{\mathrm{d}}$ & $114.20^{\mathrm{c}}$ & $5.11^{\mathrm{a}}$ \\
LSD $(0.05)$ & 1.12 & 1.30 & 0.35 \\
Variety & & \\
Burqa & $64.20^{\mathrm{a}}$ & $115.00^{\mathrm{b}}$ & 4.61 \\
Chala & $63.27^{\mathrm{b}}$ & $116.50^{\mathrm{a}}$ & 4.83 \\
Ebisa & $64.53^{\mathrm{a}}$ & $117.00^{\mathrm{a}}$ & 4.96 \\
LSD $(0.05)$ & 0.87 & 1.01 & $\mathrm{NS}$ \\
CV $(\%)$ & 1.8 & 1.2 & 7.7 \\
\hline
\end{tabular}

Means in columns with the same letter are not significantly different at $5 \%$ probability level; LSD $(0.05)=$ Least Significant Difference at $5 \%$ level; CV= coefficient of variation; $\mathrm{NS}=$ non-significant.

\subsubsection{Plant Height}

The main effect of NPS fertilizer and varieties highly significantly $(p<0.01)$ influenced plant height. Similarly, the interaction between NPS fertilizer and varieties significantly $(\mathrm{P}<0.05)$ influenced plant height. The highest plant height $(53.67 \mathrm{~cm})$ was recorded from variety Chala applied with 200 $\mathrm{kg}$ NPS ha ${ }^{-1}$ and it was statistically at par with same variety with the application of $150 \mathrm{~kg}$ NPS ha ${ }^{-1}$ while the lowest plant height $(38.27 \mathrm{~cm})$ was recorded from variety Ebisa without NPS fertilization (Table 3).

The increased plant height of fenugreek varieties with increased rate of NPS fertilizer might be due to the more availability of nutrients through chemical fertilizers application and more nitrogen fixation by bacteria. This might have helped in better absorption and subsequent utilization of nitrogen for synthesis of chlorophyll, as nitrogen is an integral part of chlorophyll results in higher photosynthesis there by producing more photosynthates leading to more plant height. It may also be due to the cumulative effect of $\mathrm{P}$ on the processes of cell division and balanced nutrition [22]. The result is in line with the findings of Alemu who reported an increase in plant height of fenugreek varieties at $50 \%$ flowering stage in response to $\mathrm{P}$ fertilization [23].
Table 3. The interaction effect of NPS and varieties on plant height (cm) of fenugreek.

\begin{tabular}{llllll}
\hline \multirow{2}{*}{ Variety } & \multicolumn{5}{l}{ NPS rate $\left(\mathbf{k g ~ h a}^{-1}\right)$} \\
\cline { 2 - 6 } & $\mathbf{0}$ & $\mathbf{5 0}$ & $\mathbf{1 0 0}$ & $\mathbf{1 5 0}$ & $\mathbf{2 0 0}$ \\
\hline Burqa & $43.00^{\text {efgh }}$ & $43.53^{\text {defgh }}$ & $44.33^{\text {def }}$ & $49.80^{\text {ab }}$ & $44.80^{\text {cde }}$ \\
Chala & $49.13^{\text {bc }}$ & $47.80^{\text {bcd }}$ & $47.73^{\text {bcd }}$ & $49.87^{\text {ab }}$ & $53.67^{\text {a }}$ \\
Ebisa & $38.27^{\text {i }}$ & $39.93^{\text {fhi }}$ & $45.13^{\text {cde }}$ & $46.73^{\text {bcde }}$ & $44.33^{\text {defg }}$ \\
LSD $_{0.05}=4.048 \mathrm{CV}(\%)=5.3$ & & & \\
\hline
\end{tabular}

Means followed by the same letter(s) in the table are not significantly different at $5 \%$ level of significance; $L S D=$ Least significance difference at $5 \%$ probability level; $\mathrm{CV}=$ Coefficient of variation.

\subsubsection{Number of Primary Branches per Plant}

The main effect of NPS was highly significant $(p<0.01)$ on the number of primary branches produced per plant while neither the main effect of varieties nor the interaction effect of NPS and varieties significantly influenced by number of primary branches per plant The number of primary branches significantly increased with the increase in NPS rate from zero to $200 \mathrm{~kg} \mathrm{ha}^{-1}$. The highest number of primary branches per plant (5.11) was recorded from 200 $\mathrm{kg}$ NPS ha ${ }^{-1}$ fertilizer while the lowest number of primary branches per plant (4.47) was recorded from without application of NPS fertilizer (Table 2).

The increase in number of branches with increase in NPS 
rate might be due to the fact that nitrogen found in the NPS fertilizer is responsible for crop branching. It also might be because of $\mathrm{P}_{2} \mathrm{O}_{5}$ involve in cell division activity, which is important for increasing plant height, number of branches and increased the plant dry weight [24]. Similarly, Data et $a l$. ; and Thapa and Maity reported that increased number of branches of fenugreek with increasing nitrogen levels up to $50 \mathrm{~kg} \mathrm{ha}^{-1}$ [25] and [26]. Likewise, Singh et al. reported that the numbers of primary and secondary branches of fenugreek were significantly influenced by application of Sulphur [27].

\subsection{Yield Components and Yield}

\subsubsection{Number of Pods per Plant}

The analysis of variance showed significant $(p<0.05)$ effect of NPS application on the number of pods per plant while the main effect of varieties and the interaction between NPS fertilizer and varieties of fenugreek did not show significant effect.

The highest number of pods per plant (25.47) was obtained from $200 \mathrm{~kg}$ NPS ha ${ }^{-1}$, however; it was statistically at par with NPS rates of 150 and $100 \mathrm{~kg} \mathrm{ha}^{-1}$ while the lowest number of pod number per plant (20.22) was obtained from no application of NPS fertilizer (Table 5). This might be due to the effect of $\mathrm{P}$ in the processes of cell division and balanced nutrition that enhanced growth and improving the reproductive performance of the plants. It might also be due to adequate availability of $\mathrm{N}$ and $\mathrm{P}$ which might have facilitated the production of more primary and secondary branches and plant height, which might, in turn, have contributed for the production of higher number of total pods.

This result is in line with the findings Ramesh et al. reported that increasing phosphorus rate up to $50 \mathrm{~kg} \mathrm{P}_{2} \mathrm{O}_{5}$ ha1 increased fenugreek pods per plant up to (38.40 [28]. Similarly, [29] have reported increased number of pods per plant of chickpea by seed inoculation and $\mathrm{P}$ fertilization. Zafar et al, have also reported that phosphorus fertilization showed significant increase in number of pods per plant of lentil due to the cumulative effect of phosphorus in the processes of cell division and balanced nutrition [22].

\subsubsection{Number of Seeds per Pod}

The analysis of variance showed that the main effect of NPS was highly significant $(p<0.01)$ and the interaction between NPS and varieties significantly $(p<0.05)$ influenced the number of seeds per pod. However, there was no significant variation among the varieties of fenugreek in number of seeds per pod.

The highest number of seeds per pod (11.89) was recorded from Burqa variety at rate of $150 \mathrm{~kg} \mathrm{NPS} \mathrm{ha}^{-1}$ fertilizer and it was statistically at par with variety Ebisa at the same rate of NPS (11.71). In contrast, the lowest number of seeds per pod (8.75) was obtained from Chala variety at no application of fertilizers (Table 4). The highest number of seeds per pod at the higher NPS rate might be because of the availability of major nutrients (NPS) in proportionate amount increases concentration of carbohydrates in seed which serve as a reservoir of carbohydrates which resulted in increased number of seeds in each pod.

The present result is in agreement with that of Solomon, who reported that the number of seeds per pod of faba bean was significantly $(p<0.01)$ affected due to the application of phosphorus rate, where the highest number of seeds per pod (3.41) was obtained from faba bean with application of $69 \mathrm{~kg}$ $\mathrm{P}_{2} \mathrm{O}_{5} \mathrm{ha}^{-1}[30]$.

Table 4. The interaction effect of NPS fertilizer and varieties on number of seeds per pod of fenugreek.

\begin{tabular}{llllll}
\hline \multirow{2}{*}{ Variety } & \multicolumn{5}{l}{ NPS rate $\left(\mathbf{k g ~ h a}^{-1}\right)$} \\
\cline { 2 - 6 } & $\mathbf{0}$ & $\mathbf{5 0}$ & $\mathbf{1 0 0}$ & $\mathbf{1 5 0}$ & $\mathbf{2 0 0}$ \\
\hline Burqa & $9.43^{\text {bcd }}$ & $9.61^{\text {bcd }}$ & $10.43^{\mathrm{b}}$ & $11.89^{\mathrm{a}}$ & $10.43^{\mathrm{b}}$ \\
Chala & $9.19^{\mathrm{cd}}$ & $9.91^{\mathrm{bc}}$ & $10.26^{\mathrm{bc}}$ & $9.87^{\mathrm{bc}}$ & $10.44^{\mathrm{b}}$ \\
Ebisa & $8.75^{\mathrm{d}}$ & $9.57^{\mathrm{bcd}}$ & $9.97^{\mathrm{bc}}$ & $11.71^{\mathrm{a}}$ & $10.01^{\mathrm{bc}}$ \\
$\mathrm{LSD}_{0.05} \mathrm{~V}$ & x NPS $=0.9891 \mathrm{CV}(\%)=5.9$ & & \\
\hline
\end{tabular}

Means followed by the same letter(s) in the table are not significantly different at $5 \%$ level of significance; $L S D=$ Least significance difference at $5 \%$ probability level; $\mathrm{CV}=$ Coefficient of variation.

\subsubsection{Thousand Seed Weight}

The analysis of variance showed that the main effect of NPS was highly significant $(p<0.01)$ on thousand seed weight. Similarly, significant variation $(p<0.05)$ was observed due to fenugreek varieties. However, the interaction between NPS fertilizer and varieties did not significantly affect this parameter. The highest thousand seeds weight $(18.44 \mathrm{~g})$ was recorded from $150 \mathrm{~kg} \mathrm{NPS} \mathrm{ha}{ }^{-1}$ while the lowest thousand seed weight (15.56 g) was recorded from no application of NPS fertilizer (Table 5). These results indicated that NPS fertilizer application contributed to increase efficiency of major nutrients and, thus, led to higher seed weight and yield.

In agreement with this result, Malik et al reported that $\mathrm{P}$ fertilizer and seed inoculation to soybean had significant influence on thousand seed weight, with the highest rate at 90 $\mathrm{kg} \mathrm{P}_{2} \mathrm{O}_{5} \mathrm{ha}^{-1}$ with Rhizobium inoculation which was statistically at par with $120 \mathrm{~kg} \mathrm{P}_{2} \mathrm{O}_{5} \mathrm{ha}^{-1}$ with inoculation [31]. Similar result was reported by Rüveyde et al. where thousand-seed weight was affected significantly $(p<0.05)$ by different doses of nitrogen and sulphur on fenugreek [32].

The variety Burqa scored significantly higher thousand seed weight $(17.31 \mathrm{~g})$ compared to Ebisa $(16.74 \mathrm{~g})$ and Chala $(16.65 \mathrm{~g})$. The reason for variation in thousand seed weight might be due to genetic characteristics of the varieties of fenugreek for this trait. This result is in agreement with the findings of Mustefa who reported that fenugreek cultivars are different in thousand seed weight [33].

\subsubsection{Aboveground Biomass}

The main effect of NPS was significant $(\mathrm{P}<0.05)$ on the aboveground biomass. However, neither the main effect of varieties nor the interaction effect of NPS and varieties significantly influenced aboveground biomass. The highest biomass yield $\left(7160 \mathrm{~kg} \mathrm{ha}^{-1}\right)$ was obtained from $200 \mathrm{~kg}$ NPS $\mathrm{ha}^{-1}$ and it was statistically at par with $150 \mathrm{~kg} \mathrm{NPS} \mathrm{ha}{ }^{-1}(7037$ $\mathrm{kg} \mathrm{ha}^{-1}$ ) whereas the lowest biomass $\left(6006 \mathrm{~kg} \mathrm{ha}^{-1}\right)$ was recorded from no NPS application (Table 5). The increase in 
biomass yield at maximum rate of NPS fertilizer may indicate that these nutrients play synergistic role in metabolism, chlorophyll formation, and photosynthesis of the plant which in turn increases the biological yield [34].

This result is in agreement with that of Alemu who reported that highest biomass yield $\left(6508.9 \mathrm{~kg} \mathrm{ha}^{-1}\right)$ of fenugreek was obtained from $26 \mathrm{~kg} \mathrm{P}$ ha- ${ }^{1}$ [23]. The result was also in line with the findings of Yilmaz who pointed out that increasing phosphorus levels up to $75 \mathrm{~kg} \mathrm{P}_{2} \mathrm{O}_{5} \mathrm{ha}^{-1}$ improved aboveground biomass of narbon vetch (Vicia narbonensis L.) at harvest by as much as $18.5 \%$ [35]. On the other hand, Rakesh et al have reported that increasing doses of S gradually increased biomass yield of mungbean [36].

Table 5. Main effect of NPS fertilizer and varieties on yield components of fenugreek.

\begin{tabular}{|c|c|c|c|c|}
\hline Treatment & Number of pod plant $^{-1}$ & Thousand seed weight (g) & Above ground biomass $\left(\mathrm{kg} \mathrm{ha}^{-1}\right)$ & Harvest index (\%) \\
\hline \multicolumn{5}{|c|}{ NPS rate $\left(\mathrm{kg} \mathrm{ha}^{-1}\right)$} \\
\hline 0 & $20.22 b$ & $15.56 \mathrm{~d}$ & $6006 \mathrm{~b}$ & 24.93 \\
\hline 50 & $21.84^{\mathrm{b}}$ & $16.29^{\mathrm{c}}$ & $6420^{\mathrm{ab}}$ & 24.72 \\
\hline 100 & $22.07^{\mathrm{ab}}$ & $16.46^{\mathrm{c}}$ & $6574^{\mathrm{ab}}$ & 25.27 \\
\hline 150 & $22.47^{\mathrm{ab}}$ & $18.44^{\mathrm{a}}$ & $7037^{\mathrm{a}}$ & 27.29 \\
\hline 200 & $25.47^{\mathrm{a}}$ & $17.76^{\mathrm{b}}$ & $7160^{\mathrm{a}}$ & 25.10 \\
\hline $\operatorname{LSD}(0.05)$ & 3.255 & 0.658 & 695.3 & NS \\
\hline \multicolumn{5}{|l|}{ Variety } \\
\hline Burqa & 23.36 & $17.31^{\mathrm{a}}$ & 6889 & 25.86 \\
\hline Chala & 22.72 & $16.65^{\mathrm{b}}$ & 6685 & 25.01 \\
\hline Ebisa & 21.16 & $16.74^{\mathrm{b}}$ & 6344 & 25.51 \\
\hline $\operatorname{LSD}(0.05)$ & NS & 0.510 & NS & NS \\
\hline CV (\%) & 15.0 & 4.1 & 10.8 & 10.3 \\
\hline
\end{tabular}

Means in a column with the same letter (s) are not significantly different at $5 \%$ probability level; LSD $(0.05)=$ Least Significant Difference at $5 \%$ level; CV= coefficient of variation; $\mathrm{NS}=$ non-significant.

\subsubsection{Seed Yield}

The main effect of NPS as well as that of variety was highly significant $(p<0.01)$ to influence the seed yield of the fenugreek varieties. The two factors also interacted highly significantly $(p<0.01)$ to influence the seed yield of the crop. The highest seed yield $\left(1980 \mathrm{~kg} \mathrm{ha}^{-1}\right)$ was recorded from variety Ebisa at rate of $150 \mathrm{~kg} \mathrm{NPS} \mathrm{ha}^{-1}$ fertilizer and it was statistically at par with variety Burqa at rate of $200 \mathrm{~kg}$ NPS ha ${ }^{-1}\left(1912 \mathrm{~kg} \mathrm{ha}^{-1}\right)$ while the lowest seed yield (1284 kg $\mathrm{ha}^{-1}$ ) was recorded from variety Chala without NPS fertilization (Table 6).

The yield increase with increased rate of NPS rate might be due to cumulative effect of more grain filling percentage and more number of seeds per pod due to the increased nutrient uptake by the plants might have stimulated the rate of various physiological processes like growth and assimilation of nutrients. In line with this result, Tolanur and Badnur reported the highest seed yield (2379 $\left.\mathrm{kg} \mathrm{ha}^{-1}\right)$ in chick pea by application of mineral and organic fertilization [37]. Similarly, Rüveyde et al. reported that the highest seed yields of fenugreek $\left(831.0 \mathrm{~kg} \mathrm{ha}^{-1}\right)$ were recorded by application of $90 \mathrm{~kg} \mathrm{~N} \mathrm{ha}^{-1}$, while the lowest values $(503.0 \mathrm{~kg}$ $\mathrm{ha}^{-1}$ ) was recorded from the control [32]. Habtegebriel et al. also reported that Rhizobium inoculation along with phosphorus application significantly influenced grain yield of faba bean, where inoculation and $40 \mathrm{~kg} \mathrm{P}_{2} \mathrm{O}_{5} \mathrm{ha}^{-1}$ resulted in $62.5 \%$ increase in grain yield over the control [38]. Seed yield increased with the increase of sulphur doses in fenugreek. Likewise, many research results showed that the highest seed yields on fenugreek was obtained from the maximum sulphur applications $[39,40]$.
Table 6. The interaction effect of NPS fertilizer and varieties on seed yield $\left(\mathrm{kg} \mathrm{ha}^{-1}\right)$ of fenugreek.

\begin{tabular}{llllll}
\hline \multirow{2}{*}{ Variety } & \multicolumn{5}{l}{ NPS rate $\left(\mathrm{kg} \mathrm{ha}^{-1}\right)$} \\
\cline { 2 - 6 } & $\mathbf{0}$ & $\mathbf{5 0}$ & $\mathbf{1 0 0}$ & $\mathbf{1 5 0}$ & $\mathbf{2 0 0}$ \\
\hline Burqa & $1621^{\mathrm{e}}$ & $1618^{\mathrm{e}}$ & $1822^{\mathrm{d}}$ & $1833^{\text {cd }}$ & $1912^{\text {ab }}$ \\
Chala & $1284^{\mathrm{g}}$ & $1548^{\mathrm{ef}}$ & $1520^{\mathrm{f}}$ & $1897^{\mathrm{bc}}$ & $1625^{\mathrm{d}}$ \\
Ebisa & $1559^{\mathrm{ef}}$ & $1511^{\mathrm{f}}$ & $1597^{\mathrm{e}}$ & $1980^{\mathrm{a}}$ & $1812^{\mathrm{d}}$ \\
$\mathrm{LSD}_{0.05} \mathrm{~V}$ & $\mathrm{NPS}=68.41 \mathrm{CV}(\%)=2.4$ & & & \\
\hline
\end{tabular}

Means followed by the same letter (s) within the table are not significantly different at $5 \%$ level of significance; $\mathrm{LSD}=$ Least significance difference at $5 \%$ probability level; $\mathrm{CV}=$ Coefficient of variation.

\subsubsection{Harvest Index}

The difference in harvest index was observed to be nonsignificant among varieties of fenugreek and NPS fertilizers. Similarly, significant variation was also not observed by the interactions of the two factors. The observed harvest index varies from 24.93 to $27.29 \%$ (Table 5). In line with this result Mehta et al reported that harvest index was not significantly affected with phosphorus levels in fenugreek [41]. However, contrary to the current result, Zafar et al. found that calculated values of harvest index showed an increasing trend in the harvest index values with application of $\mathrm{P}$ on lentil and minimum harvest index from the control plot [22]. Similarly, Ali reported that inoculation and phosphorus application exhibited significant effect on harvest index of chick pea [42].

\subsection{Economic Evaluation}

Partial budget analysis revealed that the highest net benefit (42231.67 and 40361.9 ETB ha ${ }^{-1}$ ) with marginal rate of 
return (566.84 and 542.5\%) were recorded for varieties of Ebisa and Chala respectively, while variety Burqa resulted the higher net benefit (39294.8 ETB ha ${ }^{-1}$ ) with highest marginal rate of return $\left(166.24 \%\right.$ ) at $100 \mathrm{~kg} \mathrm{NPS} \mathrm{ha}^{-1}$ (Table 7). The dominated treatments according to the dominance analysis were disregarded from further economic analysis. To identify treatments with the optimum return to the farmer's investment, marginal analysis was performed on nondominated treatments. For a treatment to be considered as a worthwhile preference to farmers, the marginal rates of return (MRR) need to be at least between 50\% and 100\% CIMMYT [9]. Thus, to draw farmers' recommendations from marginal analysis in this study, $100 \%$ return to the investment is reasonable lowest acceptable rate of return.

Accordingly, application of $150 \mathrm{~kg} \mathrm{NPS} \mathrm{ha}{ }^{-1}$ with marginal rate of returns (566.84 and $542.5 \%$ MRR) for varieties of Ebisa and Chala respectively, were above the minimum acceptable rate of return. Similarly, application of $100 \mathrm{~kg}$ NPS ha ${ }^{-1}$ with marginal rate of return $(166.24 \%)$ for variety Burqa was also above the minimum acceptable rate of return (Table 7). Therefore, application of $150 \mathrm{~kg} \mathrm{NPS} \mathrm{ha-1}$ for varieties Chala and Ebisa and application of $100 \mathrm{~kg} \mathrm{NPS} \mathrm{ha-1}$ for variety Burqa were superior rewarding treatments and these fertilizer rates can be recommended for those varieties in Ginir and other areas with similar agro-ecology condition.

Table 7. Partial budget analysis result for NPS fertilizer rate on fenugreek varieties at Ginir in 2017/18-2019/20 main cropping season.

\begin{tabular}{|c|c|c|c|c|c|c|c|}
\hline Variety & $\begin{array}{l}\text { NPS rate } \\
\left(\mathrm{kg} \mathrm{ha}^{-1}\right)\end{array}$ & $\begin{array}{l}\text { Average yield } \\
\left(\mathrm{kg} \mathrm{ha}^{-1}\right)\end{array}$ & $\begin{array}{l}\text { Adjusted yield by } \\
10 \% \text { down }\left(\mathrm{kg} \mathrm{ha}^{-1}\right)\end{array}$ & $\begin{array}{l}\text { GFB } \\
\left(\text { ETB ha' } \text { ha }^{-1}\right.\end{array}$ & $\begin{array}{l}\text { TVC } \\
\left(\text { ETB ha }^{-1}\right)\end{array}$ & $\begin{array}{l}\text { NB } \\
\left(\text { ETB ha } \text { ha }^{-1}\right)\end{array}$ & MRR (\%) \\
\hline Burqa & 0 & 1620.83 & 1458.75 & 36468.7 & 0 & 36468.7 & \\
\hline Burqa & 50 & 1618.06 & 1456.25 & 36406.3 & 1090 & 35316.3 & $\mathrm{D}$ \\
\hline Burqa & 100 & 1821.99 & 1639.79 & 40994.8 & 1700 & 39294.8 & 166.24 \\
\hline Burqa & 150 & 1832.87 & 1649.58 & 41239.6 & 2310 & 38929.6 & $\mathrm{D}$ \\
\hline Burqa & 200 & 1912.5 & 1721.25 & 43031.3 & 2920 & 40111.3 & 66.92 \\
\hline Chala & 0 & 1284.03 & 1155.63 & 28890.6 & 0 & 28890.6 & $\mathrm{D}$ \\
\hline Chala & 50 & 1548.15 & 1393.34 & 34833.4 & 1090 & 33743.4 & 347.97 \\
\hline Chala & 100 & 1520.14 & 1368.13 & 34203.2 & 1700 & 32503.2 & $\mathrm{D}$ \\
\hline Chala & 150 & 1896.53 & 1706.88 & 42671.9 & 2310 & 40361.9 & 542.5 \\
\hline Chala & 200 & 1625 & 1462.5 & 36562.5 & 2920 & 33642.5 & $\mathrm{D}$ \\
\hline Ebisa & 0 & 1559.03 & 1403.13 & 35078.1 & 0 & 35078.1 & 228.73 \\
\hline Ebisa & 50 & 1618.06 & 1456.25 & 36406.3 & 1090 & 35316.3 & 21.85 \\
\hline Ebisa & 100 & 1597.22 & 1437.5 & 35937.5 & 1700 & 34237.5 & $\mathrm{D}$ \\
\hline Ebisa & 150 & 1979.63 & 1781.67 & 44541.7 & 2310 & 42231.7 & 566.84 \\
\hline Ebisa & 200 & 1811.57 & 1630.42 & 40760.4 & 2920 & 37840.4 & D \\
\hline
\end{tabular}

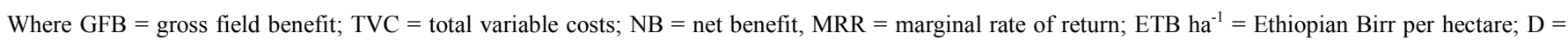
dominated treatments; Cost of NPS 1220.00 Birr $100 \mathrm{~kg}^{-1}$; Labour cost for NPS fertilizer application $=4$ person day ha ${ }^{-1}$, at 120 ETB per day; sale price of fenugreek seed 2500 Birr per $100 \mathrm{~kg}$ during harvest on farm.

\section{Summary and Conclusion}

The majority of tropical soils including that of Ethiopia have limited potential of producing high crop yields because of limitation of nutrients, particularly that of nitrogen, phosphorus and sulphur. Due to this fact, yield is usually below the genetic potential of crops. In case of fenugreek, the productivity is considerably lower than the world average due to lack of appropriate agronomic management practices particularly in relation to nutrients. One of the alternatives to address such problem is supplying well-balanced nutrients to meet the crop nutrient requirements. Therefore, an experiment was conducted with the objectives of assessing the effect of NPS fertilizer rates on growth, yield components and seed yield of fenugreek varieties under different NPS rates. The treatments consisted of factorial combinations of three varieties (Burqa, Chala and Ebisa) and five NPS application rates $\left(0,50,100,150\right.$ and $\left.200 \mathrm{~kg} \mathrm{NPS} \mathrm{ha}^{-1}\right)$ in Randomized complete block design with three replications.

Analysis of variance revealed that days to $50 \%$ flowering, days to $90 \%$ physiological maturity, number of primary branch per plant, number of pod per plant, above ground biomass, thousand, and seed weight were significantly affected due to main effect of NPS fertilizer. The maximum thousand seed weight was obtained by application of $150 \mathrm{~kg}$ NPS fertilizer $\mathrm{ha}^{-1}$. On the other hand, the maximum number of primary branches per plant, number of pods per plant and biomass yield and the shortest days to flowering and maturity were recorded by the application of $200 \mathrm{~kg}$ NPS fertilizer ha 1

Days to $50 \%$ flowering, days to $90 \%$ physiological maturity and thousand seed weight were significantly affected by main effect of fenugreek varieties. The shortest days to reach days to $50 \%$ flowering (63.27 days) were recorded from variety Chala while variety Ebisa had the longest days to reach $50 \%$ flowering date. Variety Ebisa required significantly higher number of days while variety Burqa required shortest days to reach $90 \%$ physiological maturity and scored significantly higher thousand seed weight.

The interaction effects of variety and NPS fertilizer significantly affected plant height, number of seeds per pod and seed yield. Significantly the highest plant height (53.67 $\mathrm{cm})$ was recorded from variety Chala applied with $200 \mathrm{~kg}$ NPS ha ${ }^{-1}$ while the highest number of seeds per pod (11.89) and seed yield $\left(1980 \mathrm{~kg} \mathrm{ha}^{-1}\right)$ were recorded from varieties 
Burqa and Ebisa, respectively, at rate of $150 \mathrm{~kg} \mathrm{NPS} \mathrm{ha}^{-1}$ fertilizer application.

The results of this study have indicated that yield and yield components were significantly influenced by application of NPS except harvest index. The results generally demonstrated that NPS fertilizer significantly enhanced growth and yield of the tested fenugreek varieties. Variety and NPS fertilizer rates significantly affected number of seed per pod and seed yield gave desirable results at the rate of $150 \mathrm{~kg}$ NPS fertilizer ha- ${ }^{-1}$. The fenugreek varieties, Ebisa and Chala produced the highest seed yield at $150 \mathrm{~kg} \mathrm{NPS} \mathrm{ha}^{-1}$ while variety Burqa at $200 \mathrm{~kg} \mathrm{NPS} \mathrm{ha} \mathrm{a}^{-1}$.

The economic analysis also indicated that the highest net benefit/return (42231.67 ETB ha $\left.{ }^{-1}\right)$ was recorded from variety Ebisa followed by net benefit (40361.9 $\mathrm{ETB}_{\text {ha }}{ }^{-1}$ ) from variety Chala with marginal rate of return (566.84 and $542.5 \%)$ respectively, at application of $150 \mathrm{~kg} \mathrm{NPS} \mathrm{ha}^{-1}$ while variety Burqa resulted higher net benefit (39294.8 $\mathrm{ETB} \mathrm{h}^{-1}$ ) with the highest marginal rate of return $(166.24 \%)$ at $100 \mathrm{~kg}$ NPS ha $^{-1}$ application. The lowest net return (28890.63 ETB $\mathrm{ha}^{-1}$ ) was recorded from Chala variety without NPS fertilizer application.

In general, this study provided evidence that yield and economic returns of fenugreek varieties could be improved by application of NPS fertilizer at optimum rates. Among the varieties of fenugreek tested, variety Ebisa was superior on yield performance with the application of NPS fertilizer. Thus, it can be concluded from the result of present study that the application of $150 \mathrm{~kg}$ NPS ha ${ }^{-1}$ to Ebisa and Chala varieties and $100 \mathrm{~kg}$ NPS ha ${ }^{-1}$ to Burqa variety could be recommended to enhance the productivity of fenugreek in the study area.

\section{Acknowledgements}

Author thanks Oromia Agricultural Research Institute for funding this work and the horticulture and seed spices technology generating team at Sinana Agricultural Research case team for them technical and material support.

\section{References}

[1] Khiriya, K. D., Singh, B. P. and Taneja, K. D. 2003. Effect of farm yard manure and phosphorus levels on yield, quality and nutrient uptake by fenugreek. Forage Research, 28 (4): 210214.

[2] Westphal, E., 1974. Pulses in Ethiopia: their taxonomy and agricultural significance. Center for Agricultural Publishing and Documentation. Wageningen, the Netherlands.

[3] Petropoulos G. A., Kouloumbis P. 2002 Botany, in: G. A. Petropoulos (Ed.), Fenugreek - The genus Trigonella, Taylor and Francis, London and New York. pp. 9-17.

[4] Yohanes Uloro and Richer, 1999. Phosphorus efficiency of different variety of Phaseolus vulgaris and Sorgum bicolor (L). Moend on an Altisols in Eastern Ethiopia Highlands. Ethio. J. Nat. Res. 1: 187-200.
[5] EthioSIS (Ethiopian Soil Information System). 2014. Soil analysis report. Tentative list of fertilizers required in Oromia Region for 124 surveyed woredas. Addis Ababa, Ethiopia.

[6] MoA (Ministry of Agriculture). 2014. Agricultural extension program package. Ethiopian Institute of Agricultural Research (EIAR) and Agricultural Transformation Agency (ATA). Addis Ababa, Ethiopia. Pp: 213-230.

[7] Wubishet Alemu and Chemeda Fininsa, 2016. Effects of Environment on Wheat Varieties' Yellow Rust Resistance, Yield and Yield Related Traits in South-Eastern Ethiopia. Plant, 4 (3): 14-22.

[8] GenStat. 2013. GenStat Procedure Library Release. 16 edition. VSN International Ltd.

[9] CIMMYT (International Maize and Wheat Improvement Center). 1988. From Agronomic Data to Farmer Recommendations: An Economics Training Manual. Completely revised edition. Mexico, DF. 79p.

[10] Cottenie, A. 1980. Soil and plant testing as a basis of fertilizer recommendations. FAO soil bulletin 38/2. Food and Agriculture Organization of the United Nations, Rome.

[11] Landon, J. R. (ed.). 1991. Booker tropical soil manual: A Hand Book for Soil Survey and Agricultural Land Evaluation in the Tropics and Subtropics. Longman Scientific and Technical, Essex, New York. 474.

[12] Lewis, D. C., 1999. Sulfur. 221-228. In: K. I. Peverill, L. A. Sparrow, and D. J. Reuter (eds.). Soil Analysis: An Interpretation Manual, CSIRO Publishing, Collingwood, Australia.

[13] Murphy, H. F. 1968. A report on fertility status and other data on some soils of Ethiopia. Collage of Agriculture HSIU. Experimental Station Bulletin No. 44, Collage of Agriculture: $551 \mathrm{p}$.

[14] Tekalign Tadesse. 1991. Soil, plant, water, fertilizer animal manure and compost anlysis. Working Document No. 13. International Livestock Research Center for Africa (ILCA), Addis Ababa.

[15] FAO (Food and Agriculture Organization of the United Nations). 2008. FAO fertilizer and plant nutrition bulletin: Guide to laboratory establishment for plant nutrient analysis. FAO, Rome, Italy. 203p.

[16] Gifole Gidago, Sheleme Beyene and Walelign Worku. 2011. The Response of haricot bean (Phaseolus vulgaris L.) to phosphorus application on Ultisols at Areka, Southern Ethiopia. Journal of Biology, Agriculture and Healthcare, 1 (3): 38-49.

[17] Nchimbi-Msolla S. and Tryphone G. M. 2010. The effect of the environment on iron and zinc concentrations and performance of common bean (Phaseolus vulgaris L.) genotypes. Asian Journal of Plant Science, 9: 455-462.

[18] Abera Sisay. 2015. Effect of Rhizobium inoculation and phosphorus rate on nodulation, yield and yield related traits of chickpea (Cicer arietinum L.) at Kobo, Northern Ethiopia. MSc. Thesis, Haramaya University, Haramaya, Ethiopia.

[19] Ibsa Aliyi Abdula. 2013. Agronomic and symbiotic characteristics of chickpea (Cicer arietinum L.), as influenced by Rhizobium inoculation and phosphorus fertilization under farming systems of Wolaita area, Ethiopia. MSc Thesis, Wageningen University, Wageningen, Netherlands. 
[20] Feysal Bushira, 2006. Genetic divergence and association among seed yield, yield related traits and protein content of some fenugreek (Trigonella foenum-graecum L.) landraces in Alemaya. Msc. Thesis Presented to the School of Graduate Studies of Alemaya University.

[21] Million Fikreselassie, 2009. Genetic divergence and association among seed yield, yield related traits and protein content of some fenugreek (Trigonella foenum-graecum L.) landraces in Alemaya. Msc. Thesis Presented to the School of Graduate Studies of Alemaya University.

[22] Zafar, M., M. Maqsood, R. Anser and Z. Ali, 2003. Growth and yield of lentil as affected by phosphorus. International Journal of Agricultural and Biological Sciences, 1560-8530.

[23] Alemu Dessa, 2009. Effects of phosphorus application and Rhizobium inoculation on nodulation yield and yield related traits of fenugreek (Trigonella foenum-graecum) in Sinana, south eastern Ethiopia. An MSc thesis presented to the school of graduate studies of Haramaya University. 72p.

[24] Tesfaye M. J., Liu D. L., Allan and Vance C. P. 2007, Genomic and genetic control of phosphate stress in legumes. Plant Physiol., 144.594-603.

[25] Data, S., K. Alam, R. Chatterjee, 2005. Effect of different levels of nitrogen and leaf cutting on growth, leaf and seed yield of fenugreek (Trigonella foenum-graecum L.). Indian Journal of Agricultural Sciences, 75 (9): 580-581.

[26] Thapa, U., T. K. Maity, 2004. Influence of nitrogen, phosphorus and number of cutting on seed yield of fenugreek (Trigonella foenum-graecum L.). Seed Research, 32 (1): 3335 .

[27] Singh. G. Lal, Mehta, R., Singh. R and Maheria. S. P. 2015. Performance of fenugreek (Trigonella foenum graecum L.) as influenced by sulphur and zinc. ICAR-National Research Centre on Seed Spices, Tabiji, Ajmer-305206.

[28] Ramesh, V., A. R. Agarwal and P. C. Yadav, 2002. Effect of P and weed management in fenugreek. Ann. Biol., 18: 97-8.

[29] Ali, H., Khan, M. A. and Randhawa, S. A. 2004. Interactive effect of seed inoculation and phosphorus application on growth and yield of chickpea (Cicer arietinum L.). International Journal of Agriculture and Biology, 6 (1): 110112.

[30] Solomon Ayele. 2016. Effect of phosphorus fertilizer and Rhizobium inoculation on yield components and yield of faba bean (Vicia faba L.) varieties in Mareka, southern Ethiopia. MSc Thesis, Haramaya University, Haramaya, Ethiopia.

[31] Malik, M. A., A. C. Mumtaz, Z. K. Haroon and M. A. Wahid, 2006. Growth and yield response of soybean (Glycin max L.) to seed inoculation and varying P levels. J. Agric. Res., 44 (1): $155-161$.
[32] Rüveyde Tunçtürk, a. Esen Celen, Murat Tunçtürk., 2011a. The effects of nitrogen and sulphur fertilizers on the Yield and quality of fenugreek (Trigonella foenum-graecum L.). Turkish Journal of Field Crops, 16 (1): 69-75.

[33] Mustefa F. B. 2006. Genetic divergence and association among seed yield, yield related traits and protein content of some fenugreek (Trigonella foenum-graecum L.) Landraces in Ethiopia. M.Sc. thesis submitted to the Faculty of the Department of Plant Sciences, School of Graduate Studies Alemaya University.

[34] Fageria, N. K., 2009. The use of nutrients in crop plants. CRC, Press Taylor and Francis group, Printed in U.S.A. 430pp.

[35] Yilmaz, S., 2008. Effects of increased phosphorus rates and plant densities on yield and yield related traits of narbon vetch lines. Turk Journal of Agriculture, 32: 49-56.

[36] Rakesh Kumar, Y. V Singh, Surendra Singh, A. M. Latare, P. K. Mishira and Supriya, 2012. Effect of Phosphorus and sulphur nutrition on yield and yield attributes of mungbean. Journal of Chemical and Pharmaceutical Research. 4 (5): 2571-2573.

[37] Tolanur, S. I. and Badnur, V. 2003. Effect of integrated use of organic manure, green manure and fertilizer nitrogen on sustaining productivity of rabi sorghum chick pea system and fertility of vertisol. Journal of the Indian Society of Soil Science, 51: 41-44.

[38] Habtegebriel Kiros, DestaYohannes and Weldu Yirga. 2015. Inoculation, phosphorus and zinc fertilization effects on nodulation, yield and nutrient uptake of faba bean (Vicia faba L.) grown on calcaric Cambisol of semiarid Ethiopia. Journal of Soil Science and Environmental Management, 6 (1): 9-15.

[39] Dayanand, S. O. P., 2004. Total biomass production and net return of fenugreek (Trigonella foenum-graecum L.) as influenced by phosphorus and sulphur fertilization. Haryana Journal of Agronomy, 20 (1/2): 129-130.

[40] Nehara, K. C., P. D. Kumawat, B. P. Singh, 2006. Response of fenugreek (Trigonella foenum-graecum L.) to phosphorus, sulphur and plant-growth regulators under semi-arid eastern plains zone of Rajasthan. Indian Journal of Agronomy, 51 (1): 73-76.

[41] Mehta, R. S., Anwer, M. M., Aishwath, O. P. and Meena, R. S. 2012. Studies on growth, yield and quality of fenugreek (Trigonella foenum-greaecum L.) as influenced by nitrogen, phosphorous and bio-fertilizers. Indian Journal of Horticulture, 69 (1): 94-97.

[42] Ali, A., 1993. Effects of different planting methods and phosphorus levels on the performance of Vigna radiate L. Pakistan Journal of Agriculture Research, 14: 162-168. 